(С) Л.І. Самчук, Н.В. Лисиця, 2012 ISSN 2076-8184. Інформаційні технології і засоби навчання. 2012. №2 (28). Режим доступу до журналу: http://www.journal.iitta.gov.ua

УДК 025.35:004.78:[026:37(477)]

Самчук Лариса Іванівна, завідувач відділу наукової інформаційно-бібліографічної діяльності Державної науково-педагогічної бібліотеки України ім. В. О. Сухомлинського, м. Київ, е-mail: Larisa1962@gala.net

Лисиця Наталія Василівна, науковий співробітник відділу наукової інформаційнобібліографічної діяльності Державної науково-педагогічної бібліотеки України ім. В. О. Сухомлинського, м. Київ, e-mail: inform_bibl@i.ua

\title{
РОЗВИТОК КООПЕРАТИВНОЇ ДІЯЛЬНОСТІ ОСВІТЯНСЬКИХ БІБЛІОТЕК УКРАЇНИ $З$ ФОРМУВАННЯ ЕЛЕКТРОННИХ КАТАЛОГІВ
}

\begin{abstract}
Анотація
Розвиток сучасних інформаційних технологій, у першу чергу Інтернеттехнологій, зумовлює необхідність суттєвих змін у роботі бібліотек, спрямованих на оптимізацію їхньої роботи. Одним із найперспективніших напрямків є об'єднання бібліотек у корпорації з метою спільної скоординованої обробки масивів інформації, що дозволяє уникнути дублювання в роботі й досягти більшого результату 3 меншими витратами часу і зусиль.

У статті зроблено огляд стану діяльності бібліотечних консорціумів, асоціацій, корпорацій зарубіжних країн (США, країн Свропи, СНД тощо), висвітлено досвід становлення вітчизняних бібліотечних об’єднань, зокрема освітянських бібліотек України на базі Державної науково-педагогічної бібліотеки України імені В. О. Сухомлинського.
\end{abstract}

Ключові слова: корпорації, кооперативна діяльність, бібліотечні об’єднання, електронний каталог, обмін записами, мережа освітянських бібліотек, ДНПБ України ім. В. О. Сухомлинського.

Постановка проблеми. Головне в роботі сучасної бібліотеки - повнота й оперативність задоволення інформаційних запитів користувачів. Жодна бібліотека у світі ніколи не була і не буде самодостатньою. I особливо це очевидно зараз, у часи переможної ходи Інтернету. Процеси спільної роботи стають не тільки бажаними, але 
й необхідними. Бібліотечна спільнота нині особливо гостро потребує найактивнішої корпоративної інформаційної взаємодії.

Бібліотечною корпорацією (кооперацією), зазвичай, називають об’єднання декількох бібліотек для реалізації спільних цілей і завдань, у першу чергу пов’ язаних зі створенням i комплексним використанням інформаційних ресурсів. Функціонування бібліотек у рамках корпорацій передбачає наявність тісних професійних зв'язків між учасниками, обов'язкове виконання єдиних правил і норм, узгодження рішень і дій, спрямованих на кінцевий результат.

Аналіз останніх досліджень і публікацій. Накопичений досвід щодо створення, розвитку корпоративних проектів і практики побудови взаємодії бібліотек на сучасному етапі найповніше представлений у працях таких зарубіжних i вітчизняних бібліотекознавців, як Я. Л. Шрайберг [15; 16], Ф. С. Воройський [3; 4], Н. В. Соколова [13; 14], О. В. Ліндеман [7; 8], І. О. Давидова [5], Т. Павленко [9], Т. Ярошенко [16], Т. Колесникова [6], О. І. Племнєк [10] та інші, у щорічних матеріалах і доповідях Міжнародних конференцій „Бібліотеки та асоціації в світі, що змінюється: нові технології та нові форми співробітництва”, „Бібліотеки та інформаційні ресурси в сучасному світі науки, культури, освіти та бізнесу” [1;2].

Метою публікації $€$ висвітлення досвіду співпраці освітянських бібліотек України щодо обміну електронними записами аналітичного розпису періодичних видань, окреслення проблемних питань і напрямів їх вирішення.

Основна частина. Корпоративні бібліотечні системи вже мають свою історію. У зарубіжних країнах бібліотечні корпорації почали створюватися 3 1970-х рр., що стало початком міжбібліотечного співробітництва і кооперативних робіт у цій сфері. У результаті ефективної роботи корпорацій значна кількість бібліотек зарубіжних країн відмовилися від виконання повномасштабних робіт з каталогізації своїх фондів, підвищили рівень інформаційного обслуговування користувачів, розширили номенклатуру продуктів і послуг. За кордоном успішно функціонують більше 200 міжнародних, національних i регіональних об'єднань: консорціумів, асоціацій, корпорацій, комп'ютерних бібліотечно-інформаційних мереж. Низка Асоціацій (IATUL, CLA, IALL) були створені ще в 40-50 pp. XX століття. Найбільш яскравим і типовим прикладом зарубіжного бібліотечного консорціуму $\epsilon$ широко відома американська корпорація OCLC (Online Computer Library Centre). Вона була створена 
в 1967 році як бібліотечний онлайновий центр, який об’єднує діяльність коледжів штату Огайо (Ohio College Library Centre - таж сама абревіатура OCLC, яка збереглася зараз, але має вже іншу назву), це дозволило 54 коледжам штату обмінюватися інформаційними ресурсами, скоротити свої фінансові витрати на каталогізацію і покращити доступ до бібліотечних фондів. OCLC об' єднує бібліотеки 95 країн світу. 3 появою персональних комп’ютерів відкрилися нові можливості. У 1972 р. в США було зареєстровано 125 консорціумів академічних бібліотек. Вони стали основою для розвитку сучасних корпоративних бібліотечно-інформаційних технологій.

Університетські бібліотеки стали також ініціаторами створення і членами інших відомих консорціумів, таких, наприклад, як створений в 1974 p. RLIN (Research Libraries Information Network), який об'єднує 160 організацій у США та інших країнах, і є головним конкурентом OCLC у світі і, у першу чергу, у США.

У країнах Європи й Азії корпорації бібліотек почали створюватися пізніше. Датська електронна науково-дослідна бібліотека (DEF), створена в 1997 p. 3 ініціативи міністерств культури, науки і освіти, нині об'єднує близько 300 академічних, публічних i спеціальних бібліотек країни. DEF займається ліцензуванням електронних ресурсів, створених данськими організаціями, кооперативним оцифруванням інформаційних багатств країни, наданням дистанційного доступу до електронних ресурсів найбільших постачальників (у т. ч. Crossfire, Kluwer, Springer, UMI, Highwire, JSTORE, Elsevier). Консорціум фінансується спільно урядом і організаціями-членами. Аналогічним проектом $є$ i Національна електронна бібліотека Фінляндії (FinELib), яка об'єднує більше сотні академічних, політехнічних, науково-дослідних і публічних бібліотек. У найбільших країнах Європи діють декілька різноманітних консорціумів, серед яких $\epsilon$ i спеціалізовані, і регіональні. Наприклад, німецький консорціум HeBIS (Hochschul-und Landesbibliotheken,), до якого входять 14 академічних, спеціальних і публічних бібліотек землі Гессен. Національною бібліотекою Шотландії і Бібліотекою Единбурзького університету був створений консорціум Encompass. Його мета визначення і придбання систем для роботи з фондами електронних документів, інтернет-ресурсами, а також для спрощення доступу до ліцензійних ресурсів. 
Цікавою є історія створення турецьких інформаційних консорціумів. За участю приватних інвесторів був створений ULAKBIM (Турецький академічний центр інформації), мета якого - комплектування фондів бібліотек університетів країни як центральних сховищ зарубіжної друкованої періодики і їх об'єднання в Державну академічну мережу для недорогого доступу в Інтернет, забезпечення кожного державного вищого i середнього навчального закладу хоча б одним сучасним комп'ютером. 31999 р. почалося створення і національних консорціумів - Web of Science, 17 членів якого уклали угоду з групою ISI на доступ до низки відомих баз даних (БД), у т. ч. Science Citation Index та Journal Citation Reports. На базі ULAKBIM створено консорціум Анкари. Нині в Туреччині діє вже близько десятка подібних об'єднань.

Сучасні російські бібліотечні консорціуми об'єднують бібліотеки різної відомчої і регіональної підпорядкованості. Водночас вони різняться рівнем розвитку техніки, телекомунікаційної інфраструктури і технології.

Нижче наведені приклади російських консорціумів.

- Російський інформаційно-бібліотечний консорціум (РІБК), створений у 2003 р., об'єднує п'ять найбільших бібліотек Росії (Всеросійська державна бібліотека іноземної літератури, Наукова бібліотека Московського державного університету, Парламентська бібліотека, Російська державна бібліотека, Російська національна бібліотека (Санкт-Петербург)).

- Асоціація регіональних бібліотечних консорціумів (АРБІКОН) була створена у 2002 р. для координації діяльності бібліотек із підвищення якості сервісів за рахунок модернізації управління бібліотечними ресурсами у разі об'єднання в бібліотечні консорціуми. Нині АРБІКОН об'єднує близько 160 бібліотек (індивідуальні члени) і 13 консорціумів (корпоративні члени) у рамках єдиної неформальній організаційно-технологічної системи, яка надає інформаційні ресурси для корпоративного використання.

• Національний інформаційно-бібліотечний центр „ЛІБНЕТ” (Центр ЛІБНЕТ) був створений у формі автономної некомерційної організації у квітні 2001 р. двома провідними бібліотеками Росії: Російською державною бібліотекою і Російською національною бібліотекою за підтримки Міністерства культури Російської Федерації. Його метою є створення національної системи корпоративної каталогізації на основі 
системи національних форматів RUSMARC, зниження витрат російських бібліотек на машиночитну каталогізацію за високої якості бібліографічних записів (суворе дотримання російських правил каталогізації, авторитетний контроль). Центр ЛІБНЕТ об’ єднує 189 учасників.

- Проект „Міжрегіональний аналітичний розпис статей” (МАРС) існує з 2001 року і в даний час об'єднує 205 бібліотек різних систем і відомств, які загальними зусиллями створюють зведену базу даних, яка містить повний аналітичний розпис 1856 журналів. У проекті беруть участь не тільки бібліотеки з різних регіонів Росії, а й із Білорусі, України і Казахстану.

Бібліотека Академії управління при Республіці Білорусь у 2005 році стала ініціатором республіканського консорціуму 3 аналітичного розпису документів LibKARD на базі автоматизованої інтегрованої бібліотечної системи „Alis” (м. Мінськ). На сьогодні у проекті беруть участь 14 бібліотек різних установ, систем і відомств республіки, що працюють в ідентичних програмах. Ведення зведеного каталогу аналітичних записів покладено на бібліотеку Академії управління.

Інформаційний консорціум Казахстану, створений в листопаді 2001 року Республіканською науково-технічною бібліотекою i Центральною науковою бібліотекою Міністерства освіти і науки як некомерційне добровільне об'єднання, сприяє в забезпеченні вільного доступу користувачів до інтегрованих інформаційних ресурсів через Інтернет. На сьогодні членами корпоративного об'єднання, основу якого складають вузівські бібліотеки, є 50 бібліотек і організацій, що мають доступ до БД ЕBSCO.

В Україні впровадженням корпоративних проектів займаються бібліотеки Києва, Житомира, Вінниці, Миколаєва, Кіровограда та інших міст.

Національна бібліотека України ім. В. І. Вернадського в рамках організації і формування електронних інформаційних ресурсів бере участь в шести корпоративних проектах: „Наукова електронна бібліотека України”, „Наукова періодика України”, „Система реферування української наукової літератури”, „Інтранет/Екстранетресурси”, „Система наукових електронних видань України "Бібліотека суспільству"'”, „Наукова спадщина України”.

Певний досвід корпоративної діяльності набули бібліотека Харківського національного університету внутрішніх справ, Центральний український 
кооперативний каталог (ЦУКК), що реалізується з ініціативи Кіровоградської ОУНБ ім. Д. І. Чижевського, Харківська державна наукова бібліотека імені В. Г. Короленка та Асоціація сучасних інформаційних бібліотечних технологій (АСІБТ), Донецька обласна універсальна наукова бібліотека, корпорації медичних бібліотек, Корпоративна мережа бібліотек м. Маріуполя, бібліотечна корпорація вузівських бібліотек м. Миколаєва тощо.

Державна науково-педагогічна бібліотека України імені В. О. Сухомлинського - головна бібліотека мережі освітянських бібліотек МОНмолодьспорту України і НАПН України - одним із пріоритетних своїх завдань вважає формування повноцінного всеукраїнського галузевого ресурсу як сегменту інформаційного простору держави на базі бібліотеки у традиційній і електронній формі [11]. 3 метою системного інформаційного забезпечення розвитку освіти і науки колективом ДНПБ України ім. В. О. Сухомлинського у 2009 р. розпочато обмін електронними записами (Е3) аналітичного розпису періодичних видань з освітянськими бібліотеками України.

Основні цілі обміну:

- спільне створення бібліографічних описів документів і поповнення БД „Періодика” електронного каталогу (ЕК) у ДНПБ України ім. В. О. Сухомлинського і мережі освітянських бібліотек;

- сприяння якісному інформаційному забезпеченню користувачів бібліотек;

- модернізація структури управління бібліотечними ресурсами;

- оперативне використання інформаційних ресурсів віддалених бібліотек через Інтернет.

Діяльність даного проекту базується на визнаних у всьому світі кооперативних принципах.

1. Добровільне $i$ відкрите членство. Кооперативи $\epsilon$ добровільними об'єднаннями, відкритими для тих, хто може користуватись їхніми послугами i готовий взяти на себе відповідальність, пов’язану з членством.

2. Демократичний членський контроль. Кооперативи є демократичними об’єднаннями, контролюються своїми членами, які беруть участь у розробці стратегії розвитку кооперативів і прийнятті рішень.

3. Автономія $i$ незалежність. Кооперативи $є$ автономними об’єднаннями самодопомоги. 
4. Освіта, підвищення кваліфікащії, інформащія. Кооперативи дбають про освіту і підвищення кваліфікації своїх членів, аби кожен із них міг робити ефективний внесок у розвиток кооперативу.

Перед початком роботи були визначені етапи створення проекту: підготовчий, основний, заключний. На першому етапі визначалися учасники обміну, уточнювався список журналів для аналітичного опису і список обов'язкових для заповнення полів. Першими учасниками обміну стали бібліотеки-користувачі програмного продукту „ІРБІС”. На 1.01.2012 p. ДНПБ України ім. В. О. Сухомлинського налагодила співпрацю 3 Миколаївською науково-педагогічною бібліотекою, Львівською обласною науково-педагогічною бібліотекою, вишівськими бібліотеками (наукова бібліотека Національного педагогічного університету імені М. Драгоманова, бібліотеки Вінницького державного педагогічного університету імені М. Коцюбинського, Кримського гуманітарного університету (м. Ялта), Кримського інженерно-педагогічного університету м. Сімферополь), Ніжинського державного університету імені Миколи Гоголя, комунального вищого навчального закладу „Херсонська академія неперервної освіти”) та іншими книгозбірнями.

Після проведення тестового обміну опису журналів був складений перелік обов'язкових для заповнення полів: назва статті, автор, відомості про джерело, у якому опублікована стаття, предметна рубрика, ключові слова, персоналія й анотація, якщо назва статті не розкриває іiі змісту.

На першому етапі виникли певні проблеми. Головною з них була різна якість записів, що створюють учасники проекту. Усі бібліографічні записи, надіслані бібліотеками, у ДНПБ України ім. В. О. Сухомлинського переглядаються i, у разі необхідності, редагуються. 3 метою досягнення необхідного рівня якості записів організовано взаємодію між бібліографами бібліотек-партнерів.

На сьогодні вже можемо підвести підсумки за результатами майже трьох років співпраці. За період травень 2009 - грудень 2011 р. ЕК ДНПБ України ім. В. О. Сухомлинського поповнився на 5295 записів, з них за вісім місяців 2009 р. 520 записів, за 2010 р. - 2088, за 2011 р. - 2687. У свою чергу, ДНПБ України ім. В. О. Сухомлинського надіслала бібліотекам-учасницям обміну 14051 запис, з них за вісім місяців 2009 р. - 1974, за 2010 р. - 4429, за 2011 р. - 7648 записів. Спільними 
зусиллями учасників обміну здійснюється розпис 125 назв журналів України і Росії 3 питань педагогіки і психології.

Перший етап співпраці показав, що в рамках проекту мають постійно діяти такі органи:

• координаційна рада (здійснює координацію робіт усередині проекту й поза ним);

- програмно-технічна рада (консультує учасників про роботу з програмним забезпеченням);

- методична рада (працює над єдиною методикою створення аналітичного бібліографічного опису документа, консультує учасників проекту стосовно правил заповнення полів бази даних);

- рада з підвищення кваліфікації (консультує фахівців бібліотек-учасниць щодо підготовки бібліографічних записів);

• служба електронної доставки документів.

Другий етап розпочався 3 підготовки фахівцями ДНПБ України ім. В. О. Сухомлинського нормативно-методичної бази проекту. Створенню нормативно-методичних документів у ДНПБ України ім. В. О. Сухомлинського приділяється особлива увага, оскільки записи, отримані від бібліотек-учасниць, повинні бути однакової повноти і якості. У 2011 році підготовлено такі документи:

• договір, що регламентує спільну діяльність й обов'язки учасників;

- список журналів із зазначенням бібліотек, відповідальних за їх аналітичний розпис;

- інструкція щодо порядку заповнення полів для створення аналітичного запису в БД „Періодика” ЕК, у якій наведено детальний опис заповнення кожного поля, приклади заповнення для різних випадків;

- інструкція щодо порядку заповнення полів для створення бібліографічного запису періодичного видання в цілому в БД „Періодика” ЕК.

Розроблені інструкції і рекомендації стануть обов'язковими до виконання всіма учасниками проекту.

Нині проблема кооперації набуває особливої актуальності. Слід зауважити, що досвід спільної роботи освітянських бібліотек наочно доводить перспективність кооперативного підходу, що забезпечує: 
- вільний i широкий доступ усіх категорій користувачів до бібліотечноінформаційних ресурсів;

- скорочення економічних і фізичних витрат учасників кооперативних робіт на створення й підтримку ЕК завдяки одноразовому уведенню бібліографічного запису і його багаторазовому використанню всіма учасниками й користувачами;

• підвищення кваліфікації персоналу;

- обмін досвідом між учасниками проекту;

- підвищення ефективності й оперативності обслуговування;

• підвищення рейтингу бібліотек.

Координація і кооперація зусиль необхідні для задоволення інформаційних потреб сучасного користувача, забезпечення оперативного доступу до бібліотечноінформаційних ресурсів, зокрема ЕК. Саме тому співпраця і взаємодія бібліотек $\epsilon$ надзвичайно важливими й актуальними.

\section{Список використаних джерел}

1. Библиотеки и ассоциации в меняющемся мире: новые технологии и новые формы сотрудничества // Материалы Междунар. конф. [Електронний ресурс]. - М., 1999-2003. - Режим доступу : http://www.gpntb.ru/win/inter_events/index21.html. Назва з екрана.

2. Библиотеки и информационные ресурсы в современном мире науки, культуры, образования и бизнеса // Материалы Междунар. конф. [Електронний ресурс] - M., 2004-2008. - Режим доступу : http://www.gpntb.ru/win/inter_events/index21.html. - Назва з екрана.

3. Воройский $\Phi$. С. Корпоративные автоматизированные библиотечноинформационные системы: состояние, принципы построения и перспективы развития : аналит. обзор / Ф. С. Воройский, Я. Л. Шрайберг. - М. : [б. и.], 2003. - 129 с.

4. Воройский Ф. С. Региональные корпоративные библиотечные системы России: опыт последних трех лет глазами участников движения [Електронний ресурс] / Воройский Ф. С., Шрайберг Я. Л. - M., 2002. - Режим доступу : http://www.nbuv.gov.ua/articles/crimea/2002/sec1114/Doc2.HTML. - Назва з екрана.

5. Давидова I. О. Корпоративні бібліотечні об’єднання як результат формування спільної комунікаційної стратегії / I. О. Давидова // Вісн. Харк. держ. акад. культури : зб. наук. пр. / М-во культури і туризму України, Харк. держ. акад. культури, Акад. 
мистецтв України, Ін-т культурології. - Х., 2009. - Вип. 25. - С. 68-75. - Бібліогр. : 5 назв.

6. Колесникова T. Інтеграція бібліотек ВНЗ України як умова створення бібліотечного сегменту національного інформаційного простору / Тетяна Колесникова // Бібл. форум України. - 2010. - № 4. - С. 5-8.

7. Линдеман E. B. Организационные и технологические основы создания корпоративных информационных ресурсов библиотечных консорциумов [Електронний ресурс] : автореф. дисс. ... канд. техн. наук : 05.25 .05 „Информационные системы и процессы, правовые аспекты информатики” / Елена Владимировна Линдеман. - M., $2005 . \quad$ - Режим доступа : http:// www.lib.ua_ru.net/diss/cont/222627.html. - Назва з екрана.

8. Линдеман E. B. Особенности организации и технологии создания информационных ресурсов в развивающейся корпорации на современном этапе: опыт Корпоративной сети московских библиотек / Е. В. Линдеман // Науч. и техн б-ки. 2004. - № 3. - C. 55-59.

9. Павленко T. Модель корпоративного проекта по формированию сводного электронного каталога: из опыта медицинских библиотек Украины / Татьяна Павленко // Бібл. форум України. - 2010. - № 1. - С. 21-26. - Библиогр. : 16 назв.

10. Племнек A. И. Интеграция и корпоративность электронных библиотек / Племнек Александр Иванович, Соколова Наталья Викторовна // Университет. кн. 2010. - Декабрь. - С. 43-48. - Библиогр. : 5 назв.

11. Рогова П. І. Інформаційний простір України: роль освітянських бібліотек у його формуванні [Електронний ресурс] / Павла Іванівна Рогова, Наталія Володимирівна Вараксіна // Інформаційні технології і засоби навчання : електрон. наук. фахове вид. / НАПН України, Ін-т інформац. технологій і засобів навчання, Ун-т менеджменту освіти. - К., 2008. - Вип. 3. - Режим доступу : http://www.nbuv.gov.ua/e_journals/ITZN/em7/content/08rpifii.htm. - Назва з екрана.

12. Саломатова О. И. Влияние корпоративных проектов на инновационную деятельность библиографов / О. И. Саломатова // Науч. и техн. б-ки. - 2005. - № 12. С. 47-54. - Библиогр. : 5 назв.

13. Соколова Н. В. Библиотечные консорциумы: куда ведут технологии... [Електронний ресурс] / Н. В. Соколова - M., 2003. - Режим доступу : 
http://www.gpntb.ru/win/inter_events/crimea2003/trud/tom2/222/ Doc7.HTML. - Назва 3 екрана.

14. Соколова Н. В. Библиотечный консорциум Санкт-Петербурга RUSLANet новый этап развития [Електронний ресурс] / Н. В. Соколова. - М., 2001. - Режим доступу : http://www.gpntb.ru/win/interevents/crimea2001/tom/sec11/Doc2.HTML. Назва з екрана.

15. Шрайберг Я. Л. Сравнительный анализ деятельности и перспектив развития отечественных и зарубежных библиотечных консорциумов. Ч. 1 / Я. Л. Шрайберг, Е. В. Линдеман // Науч. и техн. б-ки. - 2005. - № 7. - С. 5-15. - Библиогр. : 8 назв.

16. Шрайберг Я. Л. Сравнительный анализ деятельности и перспектив развития отечественных и зарубежных библиотечных консорциумов. Ч. 2 / Я. Л. Шрайберг, Е. В. Линдеман // Науч. и техн. б-ки. - 2005. - № 8. - С. 5-17. - Библиогр. : 10 назв.

17. Ярошенко T. Бібліотечні консорціуми: перспективи розвитку / Тетяна Ярошенко // Бібл. форум України. - 2006. - № 4. - С. 7-11.

\section{РАЗВИТИЕ КООПЕРАТИВНОЙ ДЕЯТЕЛЬНОСТИ ОБРАЗОВАТЕЛЬНЫХ БИБЛИОТЕК УКРАИНЫ ПО ФОРМИРОВАНИЮ ЭЛЕКТРОННЫХ КАТАЛОГОВ}

Самчук Лариса Ивановна, заведующая отделом научной информационнобиблиографической деятельности Государственной научно-педагогической библиотеки Украины им. В. А. Сухомлинского, г. Киев, e-mail: Larisa1962@gala.net Лисица Наталья Васильевна, научный сотрудник отдела научной информационнобиблиографической деятельности Государственной научно-педагогической библиотеки Украины им. В. А. Сухомлинского, г. Киев, e-mail: inform_bibl@i.ua

\section{Аннотация}

Развитие современных информационных технологий, в первую очередь Интернет-технологий, обуславливает необходимость существенных изменений в работе библиотек, направленных на оптимизацию их работы. Одним из наиболее перспективных направлений является объединение библиотек в корпорации с целью совместной скоординированной обработки массивов информации, что позволяет избежать дублирования в работе и добиться большего результата с меньшими затратами времени и усилий. 
В статье сделан обзор состояния деятельности библиотечных консорциумов, ассоциаций, корпораций зарубежных стран (США, стран Европы, СНГ и т. д.), освещен опыт становления отечественных библиотечных объединений, в частности образовательных библиотек Украины на базе Государственной научнопедагогической библиотеки Украины имени В. А. Сухомлинского.

Ключевые слова: корпорации, кооперативная деятельность, библиотечные объединения, электронный каталог, обмен записями, сеть образовательных библиотек, ГНПБ Украины им. В. А. Сухомлинского.

\section{CO-OPERATIVE ACTIVITY DEVELOPMENT OF EDUCATIONAL LIBRARIES OF UKRAINE ON ELECTRONIC CATALOGS FORMATION}

Larysa I. Samchuk, head of the Department of scientific information and bibliography activities, V. Sukhomlynskyi State Scientific and Pedagogical Library of Ukraine, Kyiv, e-mail: Larisa1962@gala.net

Nataliya V. Lysytsya, researcher of the Department of scientific information and bibliography activities, V. Sukhomlynskyi State Scientific and Pedagogical Library of Ukraine, Kyiv, e-mail: inform_bibl@i.ua

\section{Resume}

The development of modern information technologies, especially Internet technologies, requires significant changes in the work of libraries, aimed at optimizing their performance. One of the most promising areas is an association of libraries in the corporation for joint coordinated information array processing to avoid duplication and achieve greater results with less time and effort.

This article provides an overview of the activities of foreign countries (USA, Europe, CIS, etc.) library consortia, associations, corporations, highlights the experience of becoming national library associations, in particular of the educational library of Ukraine on the basis of the V. Sukhomlynskyi State Scientific and Pedagogical Library of Ukraine.

Keywords: corporation, cooperative activities, the library association, electronic catalog, records exchange, educational network of libraries, V. Sukhomlynskyi State Scientific and Pedagogical Library of Ukraine. 